Notes on the Journey to the Arpa and Ak-Sai Plateaus in Russian Turkestan Author(s): Douglas Carruthers

Source: The Geographical Journal, Vol. 36, No. 5 (Nov., 1910), pp. 563-570

Published by: geographicalj

Stable URL: http://www.jstor.org/stable/1777344

Accessed: 11-06-2016 22:53 UTC

Your use of the JSTOR archive indicates your acceptance of the Terms \& Conditions of Use, available at

http://about.jstor.org/terms

JSTOR is a not-for-profit service that helps scholars, researchers, and students discover, use, and build upon a wide range of content in a trusted digital archive. We use information technology and tools to increase productivity and facilitate new forms of scholarship. For more information about JSTOR, please contact support@jstor.org.

The Royal Geographical Society (with the Institute of British Geographers), Wiley are collaborating with JSTOR to digitize, preserve and extend access to The Geographical Journal 


\section{NOTES ON THE JOURNEY TO THE ARPA AND AK-SAI PLATEAUS IN RUSSIAN TURKESTAN.*}

\section{By DOUGLAS CARRUTHERS.}

Tнl extreme south-western Tian Shan mountains, or, more strictly speaking, the plateau region lying between the main Tian Shan range and the Alai and Pamir groups, seems to have received little attention from travellers.

'This region, although orographically a part of the Tian Shan system, in character resembles the Pamir plateau. For it is made up of a series of wide open valleys which are situated at a high altitude, and are divided one from the other by still higher ridges. In every respect they are typical "Pamirs," the three main "Pamirs" being the Arpa, Ak-sai and the Chatir Kul. These are walled in on the south by the Kashgar range, and on the west by the Ferghana mountains. Northwards this plateau region is hemmed in by the Jaman Davan and At-bishi ranges, and eastwards by the Kok-Shal.

These plateaus are not particularly difficult of access, but they lie off the main lines of communication in Central Asia, and no routes cross them. The road from the Ferghana to Kashgar passes to the south, whilst the means of communication between the Ferghana and Tian Shan lies up the Narin river; and travellers from the Tian Shan to Kuldja invariably take the desert route.

There is, however, a Russian road leading from the town of Narin northwards to Tokmak, and a road has been planned, and, indeed, partly constructed between Narin and Kashgar. It was by that route that the only previous British traveller to cross the plateaus made his way. This was Mr. Macartney, the well-known British agent at Kashgar, who in 1908 journeyed from that town via Chatir Kul and Narin to Tokmak, and thence by the post-road to Tashkent. Of other previous travellers, mention might be made of Mr. Ellsworth Huntington, the American geographer, who covered a certain portion of the ground over which I travelled, and whose valuable observations on the climatic effects on the Nomadic races of Central Asia are recorded in that most fascinating book 'The Pulse of Asia.' As long ago as 1873 certain members of the "Forsyth Expedition" to Kashgar got as far as the Turgart Pass and gazed down on the Chatir Kul Basin, but were not permitted to continue their explorations.

In July, 1908, I set out from Andijan in the Eastern Ferghana with two men and four horses to travel over these plateaus. Passing through 
Osh, I rode to Uskent, which is the last bazaar in Ferghana. Here the extremely rich and highly cultivated zone ends; the fields of cotton and rice, the vineyards and poplar groves come to an abrupt finish, and beyond are rolling foothills leading up to higher ranges. Uskent is a fine old town, and in bygone days must have been of some importance. There are the remains of a large Minar, like the Minar Kitan in Bokhara, only on a smaller scale. It is even said that the Khan of Uskent used to receive tribute from the town of Kashgar. The foothill country east of the Ferghana plain is very fine corn land, and is quickly being taken up by Russian emigrants. Large colonies of these are settling in the neighbourhood of Uskent and making good use of the land, hitherto only sparsely cultivated by the natives. From Uskent I got a very fine panoramic view. It seemed as if there was an almost complete and unbroken line of snow-topped ranges to the north, east, and south. The range to the east of Uskent, called the Ferghana mountains, was that which walled off the Arpa and Ak-sai plateau, and over which I intended to travel.

Routes from the rich plain of the Ferghana over this range to the Narin and Issik Kul region are many. Of these, the Yassi pass is the easiest and safest, being passable with camels, but the Kurgart to the north of this is the most direct for travellers bound for the Narin, and a road is being constructed over this pass by Russian engineers. The Kurgart pass is about 10,500 feet above sea level. The pass called Suok which leads from the source of the Kara-Kuldja river over to the Chatir-Kul plateau, and which I tried to follow, is not possible for baggage animals, and ought not to be marked as a pass on the maps. Another track of some importance leads from Uskent up the Tarz river and over by the Kara Bel pass direct to Kashgar.

Leaving Uskent, I followed up the main Kara-Kulja, which is a fine river. It flows through a wide shingly bed, and is not fordable with horses laden with baggage. At Uskent a rickety bridge spans it, for its waters are confined to a single deep channel, but some way below that town the river is broken up into so many channels that it can be crossed, with circumspection, even by laden animals. Cultivation extends up this river for about 40 versts, and up the Yassi valley for about 70 versts; beyond this only a few nomadic Kirghiz are met with. After a three days' journey I reached the head of the valley, and fell in with twelve Kirghiz, who, mounted on their shaggy ponies, were attempting to pass over the range to Chatir $\mathrm{Kul}$ and thence to Kashgar. In company with these nomads I tried the Suok pass, but we failed even to get up to the headwaters of the Kara Kuldja. After all my horses had been down amongst the rocks, and had injured themselves, I gave it up and returned, leaving the Kirghiz to go on alone. But on the following day they also came back, having failed to cress the pass. Turning north up the Sur-tash tributary, the pass 
of that name was tried and found to be comparatively easy. In a sheltered side-valley on the western bank of the Sur-tash river I saw the first clump of spruce that I had seen in nine months of travel in south-west Turkestan. In other words, this was the extreme southern limit of the Tian Shan forest-belt.

From the top of the Sur-tash pass, on the Ferghana range, a most instructive view was obtained over the plateau world to the east. Below was the Arpa " Pamir," a broad, undulating, grassy valley, with the Arpa river flowing through its centre. The Jaman Davan range, which borders the Arpa plateau on the north-east, on the north closes in and joins with the Ferghana range, thus enclosing the plateau. The Arpa river cuts through this range by a deep-cut gorge, the course of which is still dotted on the map, by an imaginary line. The Jaman Davan was an extremely rough, barren range, seamed with a labyrinth of gloomy valleys, and apparently lacking in every sort of vegetation. Only a little snow capped the highest peaks. The Ferghana range itself was much more steeply graded on the west than on the east, and carried much less snow on the west.

The distribution of flora on the Central Asiatic ranges is always remarkable and of great interest. On the Ferghana range, which runs south-south-east by north-north-west, the south-western slopes are covered with a luxuriant growth of great variety. Indeed, nowhere in south-west Turkestan have I seen such a heavy growth of grass, flowers and scrub, especially at a height of from 5000 feet to 8000 feet. Walnut and birch trees grew in the valleys, and there were little clumps of apple and oak. Higher up, the "thuia," or juniper, predominated, and, as I have recorded, a few spruce trees managed to exist. Above this, alpine pastures extended right up to the snow-line, there being a very small area of shale and rock. Compare with this, the north-eastern slopes of the same range. Here was a large area of snow and shale, and a total lack of fuel and fodder. So barren was it that I could scarcely find sufficient fodder for my horses during the following six weeks on the Arpa and Ak-sai plateau, and I could never find even enough scrub to boil a kettle with.

As regards animal life, ibex were seen close to the Sur-tash pass, and wild sheep exist in the neighbourhood of the Suok pass. Marmots were, of course, very numerous, and are of interest, for these mountains seem to be the dividing-line between the ranges of the red marmot (Arctomys litiledalei and Arctomys littledalei flavinus) and the brown marmot (Arctomys centralis). All over the Pamirs and Bokharan ranges, and indeed on all the mountains lying to the south-east of the Ferghana range, and on the south side of this range itself, the red marmot is the only representative of its genus. But immediately one passes north and east over this range the brown variety takes the place of the red. However, it is worthy of notice that on the Arpa plateau I saw the 
red and brown marmots together, as if the ranges of the two just overlapped.*

On reaching the Arpa valley, I followed it up towards the east-southeast, and journeyed for three days without seeing any signs of human life. The nature of the country was that of a high rolling plateau, so high, indeed, that although it was August, I was constantly crossing the lower portions of the snowfields that lie on the Ferghana range. On reaching the valley of the Kara-Kul, which leads up to the Suok pass from the Arpa side, I turned south, and followed up the valley until I found a large encampment of Kirghiz. These nomads had apparently exhausted the pasture on the open plateau, and now, at the end of the summer months, had retreated with their herds into the upper valleys close to the snow-line, where alone they could find sufficient grazing for their flocks. It was my experience that in August the plateaus were cropped bare by the immense herds of horses, sheep, oxen, and camels, the Kirghiz being then at the highest altitude that they over reach on the surrounding ranges.

After several days spent at this encampment, and some time being given to hunting amongst the wild turmoil of ranges that stretch to the south, I returned to the Arpa plateau and passed over into the Chatir $\mathrm{Kul}$ basin. The watershed between the two basins is scarcely noticeable. On the Chatir Kul side the vegetation became more scanty, the ground appeared saline, and there was very little animal life, even marmots being scarce. But, in spite of this, there were a good many Kirghiz in camp around the lake. There were also many of these nomads on the move, driving in front of them immense herds of cattle and horses, bound for the markets in the Ferghana. The Chatir $\mathrm{Kul}$ basin is a bleak windy place, and the mountains that surround it are barren and forbidding, and the lake itself does not look inviting. Chatir Kul is situated at 11,195 feet above sea-level. It is frequented by great numbers of wild-fowl, wild geese being very numerous, and there were also great numbers of ruddy sheldrakes, and a few waders. In many places the shores of the lake were boggy.

At this point of my journey I ran short of food, and in order to obtain flour found it necessary to go all the way to the Turgart pass, where there was a small Russian outpost. On my return to the plateau I continued my journey eastwards, and crossed, in a single day, over an almost imperceptible watershed, into the Ak-sai valley. The Ak-sai plateau is bordered on the north by the At-bashi range, over which there are two passes-the Tash-Rabot and the Bogashta-into the At-bashi valley. On the south lie the high ridges of the Kok-kia

* The specimens of marmots which I collected on the Bokharan ranges and on the Ak-sai plateau, has enabled Mr. Oldfield Thomas, of the British Museum, to classify some of the marmots of Central Asia, and to name those mentioned above as new species. 


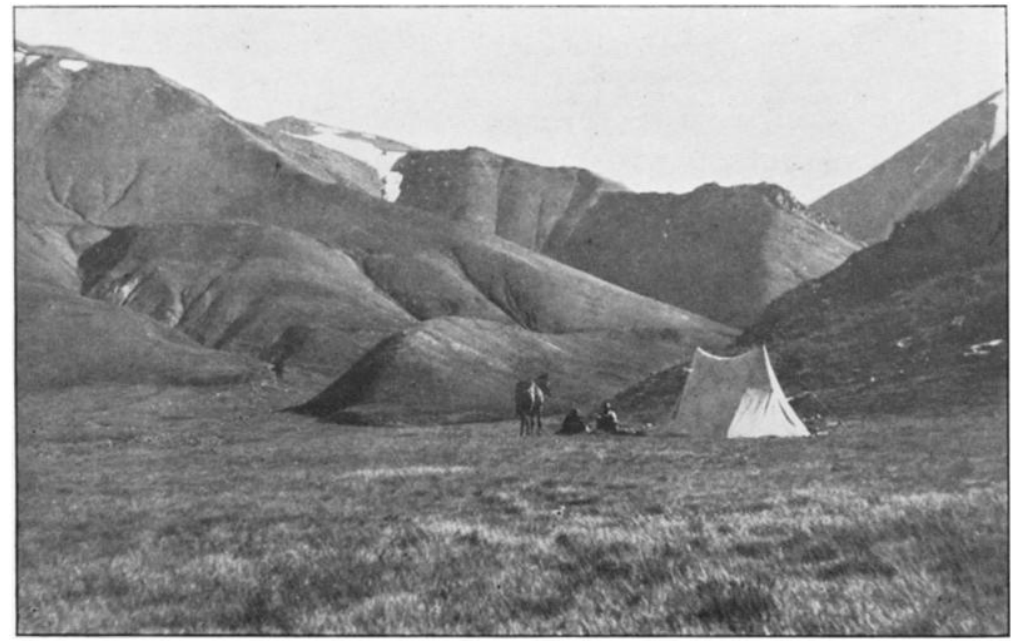

Shale slopes in the fERghana mountains at 11,000 FeEt altitude.

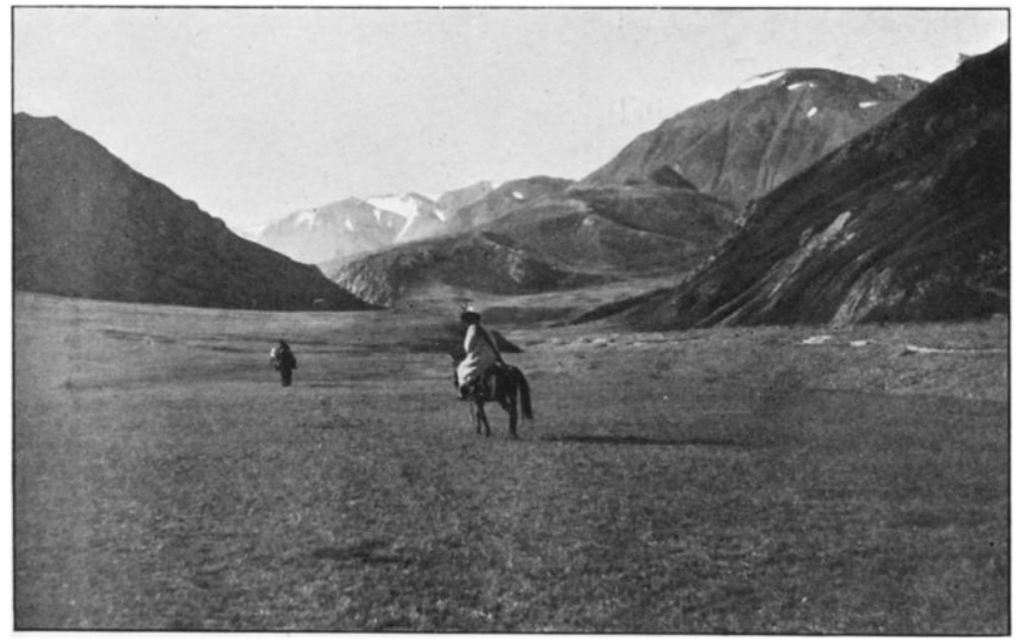

SIDE VALLEY IN THE KASHgaR MOUNTAINS, SOUTH-WEST OF CHATIR KUL.

This content downloaded from 159.178.22.27 on Sat, 11 Jun 2016 22:53:41 UTC All use subject to http://about.jstor.org/terms 


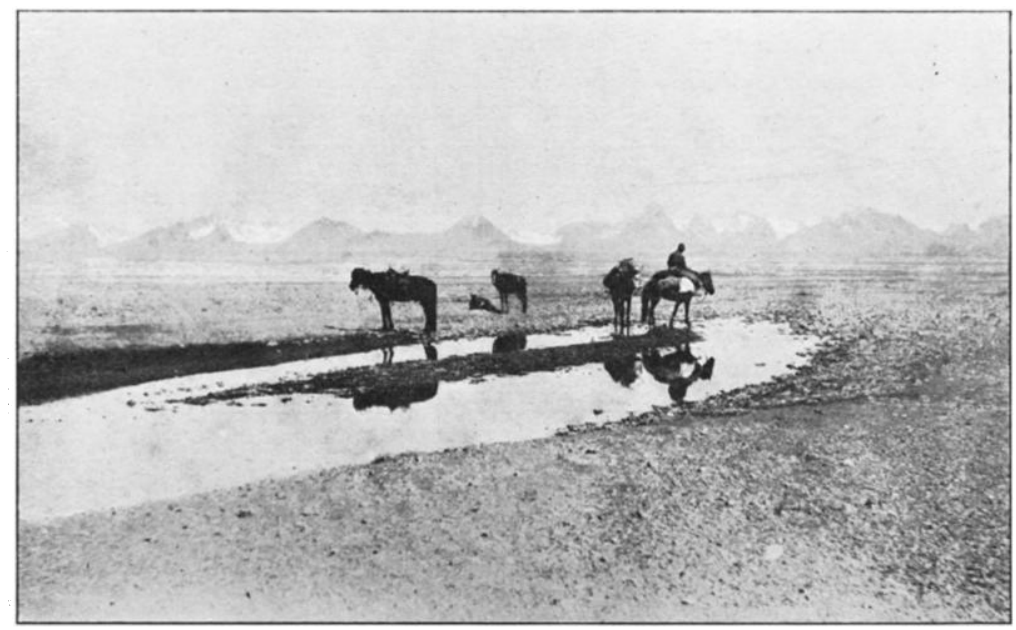

THE AK-SAI PLATEAU, LOOKING NORTH TOWARDS THE ATBASHI RANGE.

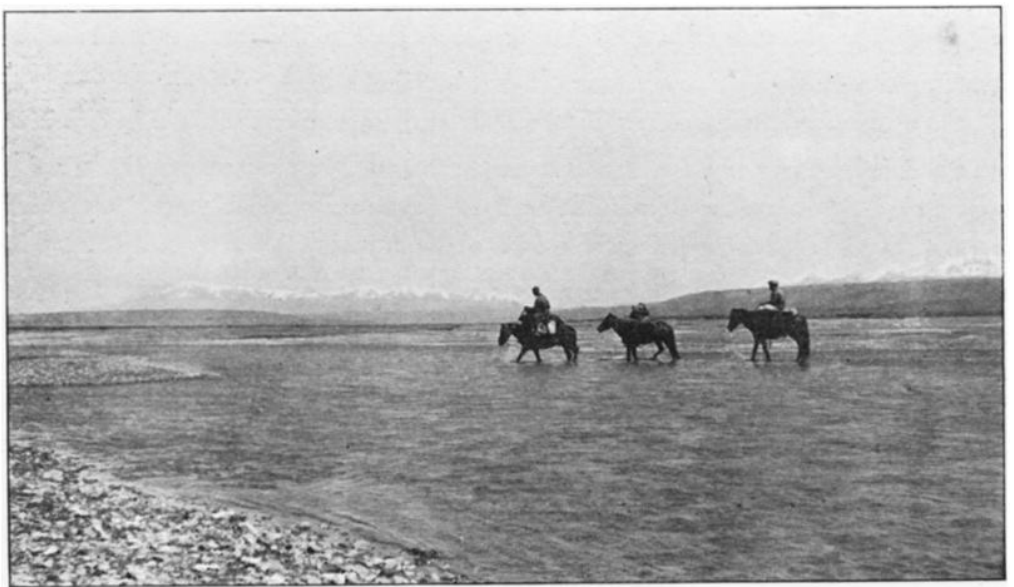

THE AK-SAI PLATEAU AND AK-SAI RIVER, LOOKING EAST TOWARDS THE KOK-KIA. 
group, whence originate the most important tributaries that go to make up the Ak-sai river, namely, the Terekty, Terek, and Kok-kia. The Ak-sai plateau is about 50 miles long, and averages 16 miles in breadth. The plateau is limited on the east by the ranges of Kok-kia and Kokshal, which close in on the plateau and hem in the Ak-sai river, so that it has cut a gorge through these ranges' very much after the style of the Arpa gorge through the Jaman Davan range.

At this season-the middle of August-there was scarcely any water in the upper Ak-sai river, neither was there any water above the ground in its tributaries, the Terek and Tekerek, but occasionally, in the dry shingly bed of the main Ak-sai, pools of water appeared, which further on increased to a running stream. The Kok-kia, however, held a great deal of water. On the Ak-sai, I noticed, there were a great many Kirghiz encamped, both on the plateau itself and also in the secluded valleys of the Kok-kia and At-bashi ranges. Now this seems remarkable, for the well-known Russian naturalist, Severtzoff, my only informant as to this region, had made several allusions in his writings to the fact that the Ak-sai was not frequented by many Kirghiz, and that in consequence the wild sheep were very numerous there and easy to shoot. That was, of course, some forty years ago. But at the time of my visit, in 1908, I found that wild sheep had disappeared from the plateau, and were only to be found in one safe retreat in the Kok-kia range. The reason is, of course, that the Kirghiz have increased, and great encampments of them annually summer on the Ak-sai plateau. Whether the Kirghiz had actually increased in numbers, or whether, preferring the Russian rule to that of China, they have come over the border from Turkestan, or whether the cause is a general climatic change, I cannot say for certain. It is my belief, however, that the latter is the true reason, for the low-lying deserts, owing to desiccation, cannot support the same amount of life that they used to do, and in consequence the higher grounds are being made more use of.

The Kirghiz, who summer at 11,000 feet on the Ak-sai, winter in the At-bashi and Narin valley, where they have permanent kraals for their flocks and there is plenty of fuel. The Kok-kia river, which I explored fairly thoroughly, has its source in the large areas of snow-fields which, even in August, cover the highest parts of the Kok-kia. Tho upper portion of the valley is an immense secluded basin surrounded by high ranges. This basin is cut off from the Ak-sai, for the lower portion of the Kok-kia river is hidden deep in an immense gorge many miles long, so that no route can lead up to the valley.

In order to reach the upper Kok-kia, I left the Ak-sai plateau, and followed up a southern tributary, called the Kuldja-bashi, and climbed over a small pass down into the Kok-kia basin. Here the Kok-kia was a wide river, flowing through a broad shingly bed, and broken up into several streams. A mile or so further down it enters the gorge. 
Upstream the main tributary of the Kok-kia is again hemmed in by gigantic ravines, through which no man can pass. I followed up the Kokkia and explored in turn the main valley and its two eastern tributaries. The upper valley was totally uninhabited, but on one or two occasions I met small parties of Kirgliz, who had come over the passes from Chinese Turkestan. The main pass is called Botmanak. These passes, however, are not difficult, for the water-shed is mainly immense rolling shale-slopes, covered with wide snow-fields, and there are no difficult rockr passages or steep climbs. Twice in two weeks I was driven out of this basin by heavy snow, but returned each time and successfully followed up the Kok-kia to its source, where I killed some fine specimens of wild sheep. The country was one of most abject desolation, where was no forest nor growth of any kind, except tufts of grass. The whole region was, indeed, a world of shale and snow.

The lower portion of the Kok-kia basin, which was without any sign of life on my first visit, was full of Kirghiz on my return, which shows the remarkable mobility of the nomads. At that season they were busy shearing the sheep, and the women were making felt mats.

The experiences I have gained since amongst the nomadic Beduin have taught me the many differences which exist between these two wandering peoples. Although they are so very alike in many respects, yet environment has caused important differences. Compare, for instance, the wealth of the Kirghiz, who have a fine country to pasture their flocks in, with the poverty of the Arabs, whose heritage is the barrenest parts of the world's surface. And, again, as a natural result, the Kirghiz are milder and more open-handed, less fanatical, and of a gentler disposition than the Beduin. For their life is more easy and free from care ; their struggle for existence is not so severe as that of the Arabs; their herds are more numerous, and their pastures more rich, neither are they constantly harried by hostile tribes. But the Beduin's struggle for existence is relentless; he lives in constant fear of enemies, and is always in want of water. Hence he has become cruel and warlike.

These Kirghiz encampments which I found at this season at a height of 10,000 and 11,000 feet, remain here only a short time, for in a month or so the snows drive them down to lower altitudes. The nomads then go into winter quarters in the warmer valleys of the At-bashi and Narin, the Ak-sai being but a summer pasturage. Even in the former valleys, sometimes, the snows are so severe that the Kirghiz lose a large percentage of their flocks.

On leaving the Kok-kia and passing across the Ak-sai plateau, I found numerous other encampments on the southern slopes of the Atbashi range. This range was entirely devoid of vegetation on the south side. The passes over it are the Tash-Rabot (12,900 feet), on the direct route from Kashgar to Narin, lying just to the north-east of Chatir Kul ; and Bogushta (12,500 feet), which crosses the centre of the range. My 


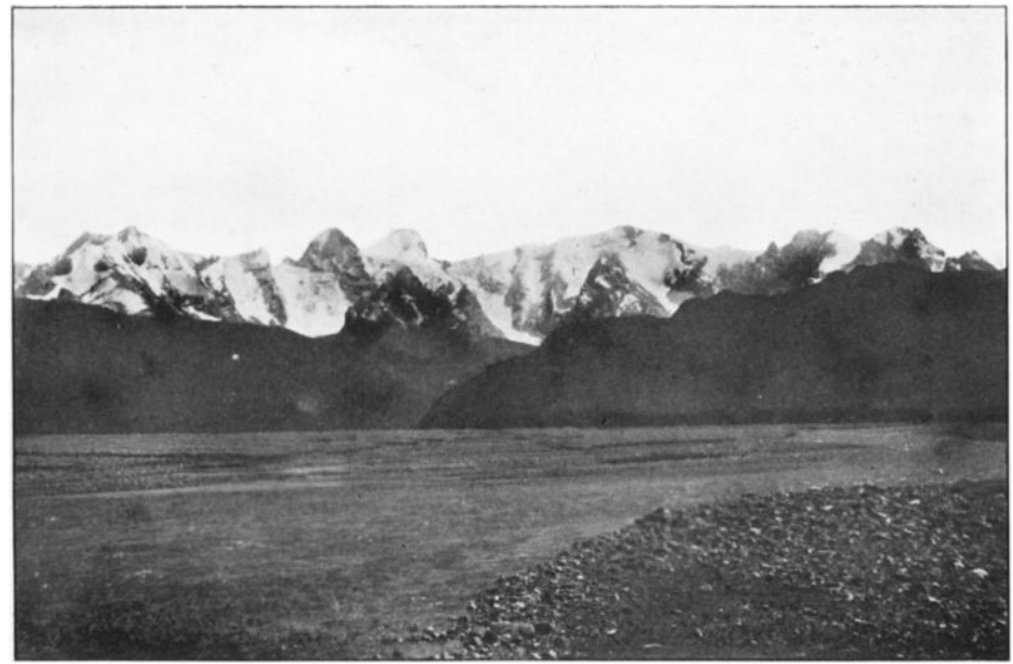

THE KOK-KIA RANGE, LOOKING SOUTH, AND THE KOK-KIA RIVER IN FOREGROUND.

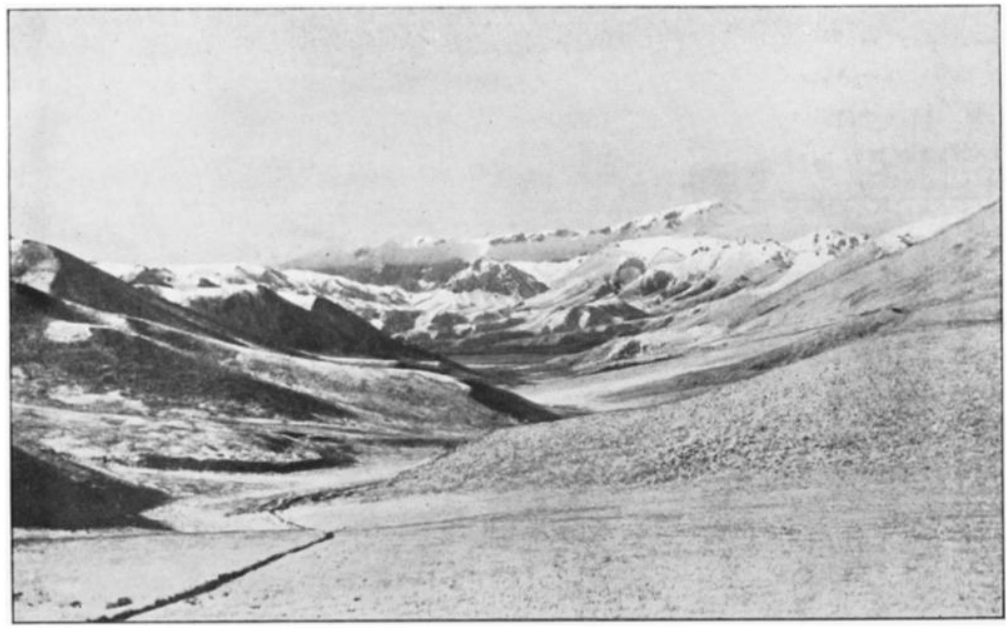

THE MAIN KOK-KIA RANGE, LOOKING EAST. 


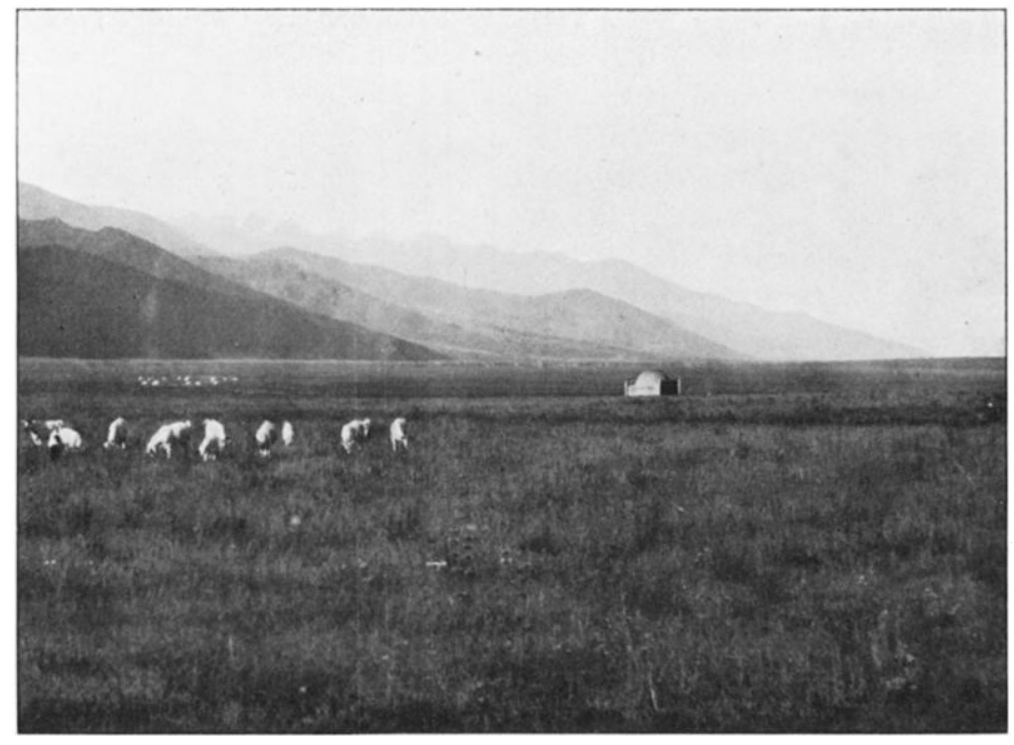

THE AT-BASHI VALLEY AND AT-BASHI RANGE.

This content downloaded from 159.178.22.27 on Sat, 11 Jun 2016 22:53:41 UTC All use subject to http://about.jstor.org/terms 
route over into the At-bashi valley led across the eastern spurs of this range, so I had but a very low and gradual ascent to make from the Ak-sai. But the difference in the scenery which bursts on the traveller's view on crossing into the At-bashi is worthy of record. I had not seen a tree, or even a shrub for six weeks, and during the last nine months in Russian Turkestan I had not come in contact with anything that one could call a forest; but on reaching the At-bashi valley I suddenly came into view of typical Tian Shan scenery. The hill slopes were covered with a wealth of grass and flowers. This was especially the case on the northern side of the At-bashi range, and on the slopes that border the valley on the south, right up to its source. The southern slopes of the ranges that border the At-bashi on the north are less densely forested. On reaching this forested region I immediately came on a great wealth of fauna, among which were the Siberian roe (Capreolus pygargus) and the Tian Shan wapiti (Curvus canadensis songaricus), this being no doubt their most southern limit.

The At-bashi is a very fine river, unfordable in its middle course, but it has that peculiarity which most of these rivers seem to possess (much to the convenience of travellers), namely, of pouring its waters in some part of its couree through a gorge so narrow that it can be spanned by a bridge. I found a native bridge of rickety construction thrown across a gorge not more than 20 feet wide, through which the whole At-bashi river forced its waters. Once on its northern bank, I followed an easy track, over a low col, into the Narin valley, where I rested for a few days at the small Russian town of Narinske.

The At-bashi valley is much like the Ak-sai, but is situated at a lower altitude. It is composed of a broad, open steppe, through which runs the At-bashi river, the ranges on the north and south rising up suddenly from the floor of the valley. This is, as I have said, a much used winter-resort of the Kirghiz. I found many kraals of mud bricks used for the herds, and a few little mosques built over the graves of Kirghiz chiefs. This gave the valley a more settled appearance, unlike the Ak-sai, which is a true " nomad's land." Familiar objects dotted the hillsides, in the shape of haycocks, for the heavy growth of these valleys supplies the winter fodder for the flocks and herds. The summer is the busy season for the Kirghiz, for it is then that they do all their work; but in the winter they form large encampments in such a valley as this, where there is ample firewood, and do little but indulge in hunting and falconry. On the road from the At-bashi to the Narin valley I found that nearly all the water was saline, and there were also many treacherous bogs, which, on several occasions, my horses fell foul of.

South of Narin, I again got on to the road which is being constructed to Kashgar, the Kashgar end of which I had seen near the Turgart pass. It was well engineered, and capable of being used for wheeled traffic, so, when completed, it will, no doubt, be of great service. Narin itself 
is quite a small place, but with a fairly large garrison of Russian soldiers. The most striking thing that I noticed here was the pitiable, but inevitable result that civilization has on the Kirghiz. In the bazaars I noticed fine specimens of this, one of the most healthy races in the world, degraded and ruined in health by the use of alcohol.

On leaving Narin my route lay down the valley for about 30 miles, through land more or less cultivated. On the way I crossed another remarkable gorge, through which the At-bashi and Kara-kein rivers, together with all their tributaries, force their combined waters before their junction with the Narin river. The gorge is but 12 feet across, and in many places the rocky walls are not 6 feet apart. It is spanned by a bridge which is only 6 paces wide, although a good 100 feet above the foaming torrent, which rushes through this narrow chasm. Between the tributaries At-bashi and Terek, the Narin valley contains some growth, and there are patches of cultivation. But west of the Terek it is very barren, and only along the river is there a jungle of scrub. The northern slopes of the Jaman Davan now burst into view, and appear to be as sterile on the north as they are on the south. On reaching the Alabuga river, I followed it up and got into a very broken and barren loëss country. There are two or three little settlements in this valley, and a certain amount of grain is grown.

On nearing the Ferghana mountains again, I noticed many caravans on the move, long trains of Bactrian camels laden with felt, and large herds of horses and sheep, hastened by their owners, for the winter was approaching, and the passes would soon be closed. All this traffic was bound for the bazaars of the Ferghana. I crossed the range by the Yassi pass, over which there is quite a good route, there being few rocks, and the actual pass is only about 9000 feet. I fell in with a caravan of sixty camels, and accompanied them over the pass, noticing the extraordinary ease with which they could accomplish it, although heavily laden. From the crest of this pass it was no distance down into the Ferghana, my route following along the Yassi valley. Dropping down from the mountains, one soon enters the regions of cultivation. The hills, which are well clothed with grass and scrub, were at this season dotted with innumerable haycocks, and the valley itself was well cultivated with maize and clover.

I passed again through the town of Uskent, and crossed the Karakuldja just below where the Yassi river joins it. The river has here been dammed in a wonderful way, and a very large proportion of the water carried off for irrigation purposes.

At the end of September I rode into Andijan and continued the journey by railway, to my headquarters at Samarkand. 


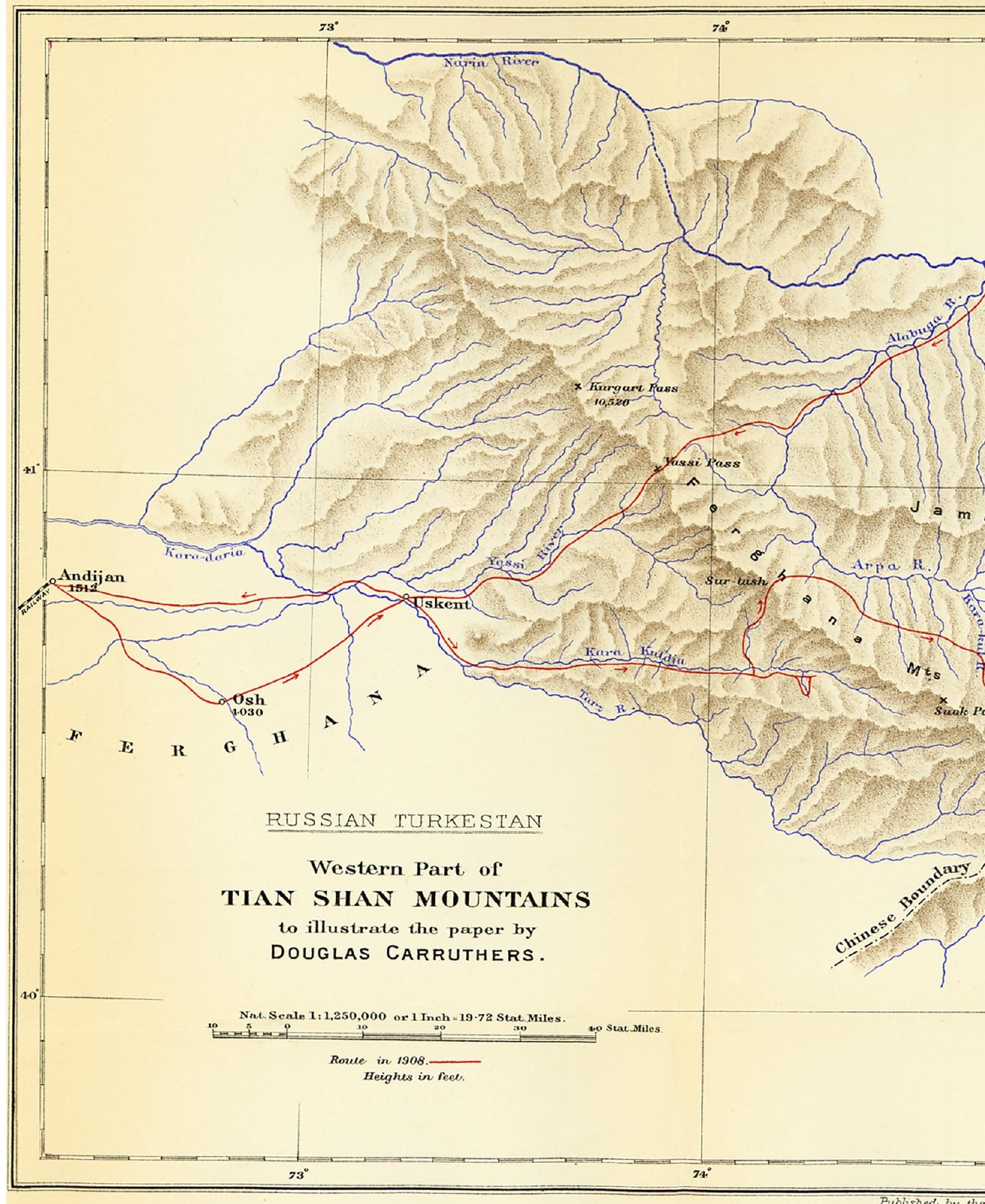




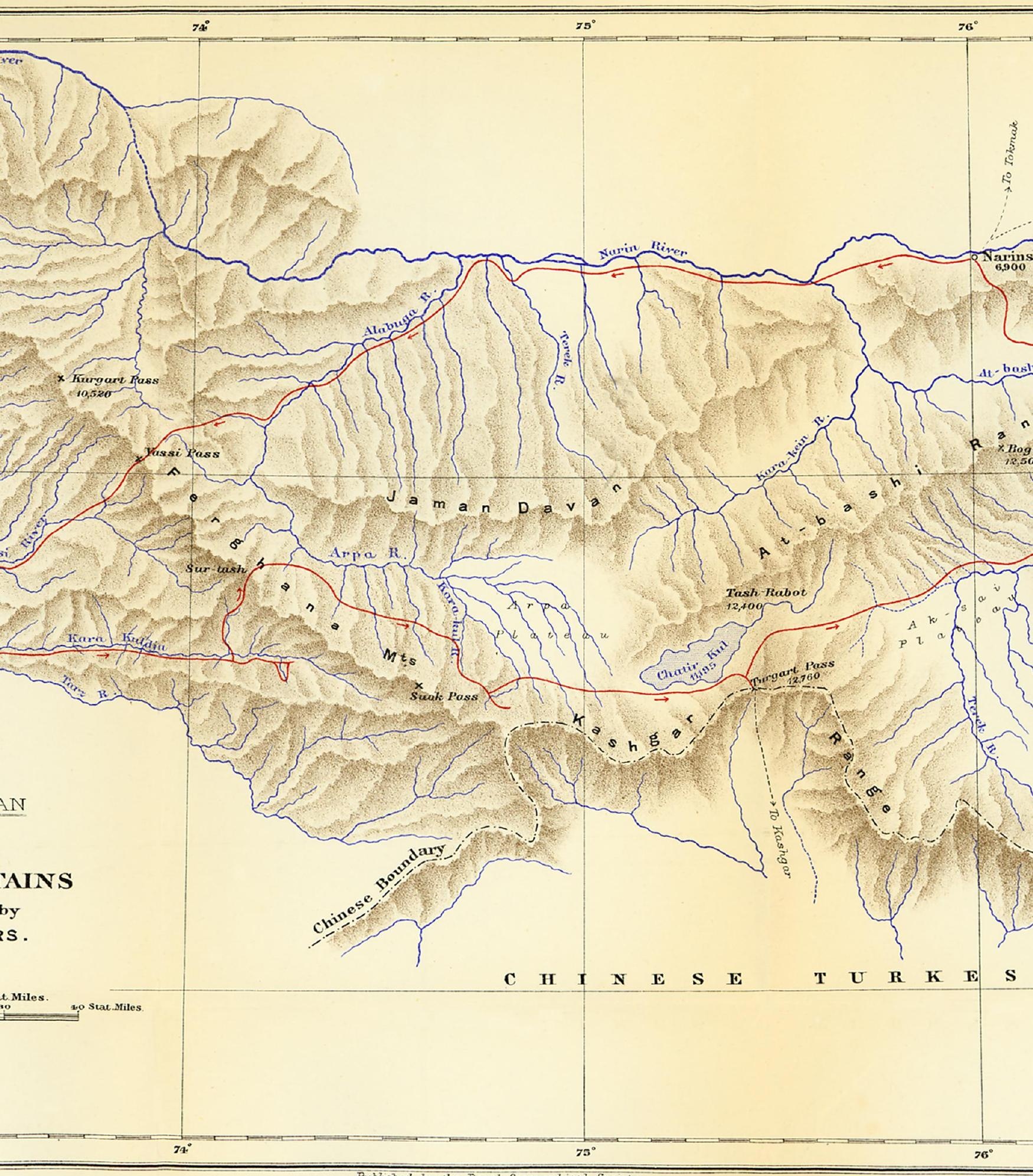

Fublished by the Rloyal Geographical Society.

This content downloaded from 159.178.22.27 on Sat, 11 Jun 2016 22:53:41 UTC All use subject to http://about.jstor.org/terms 


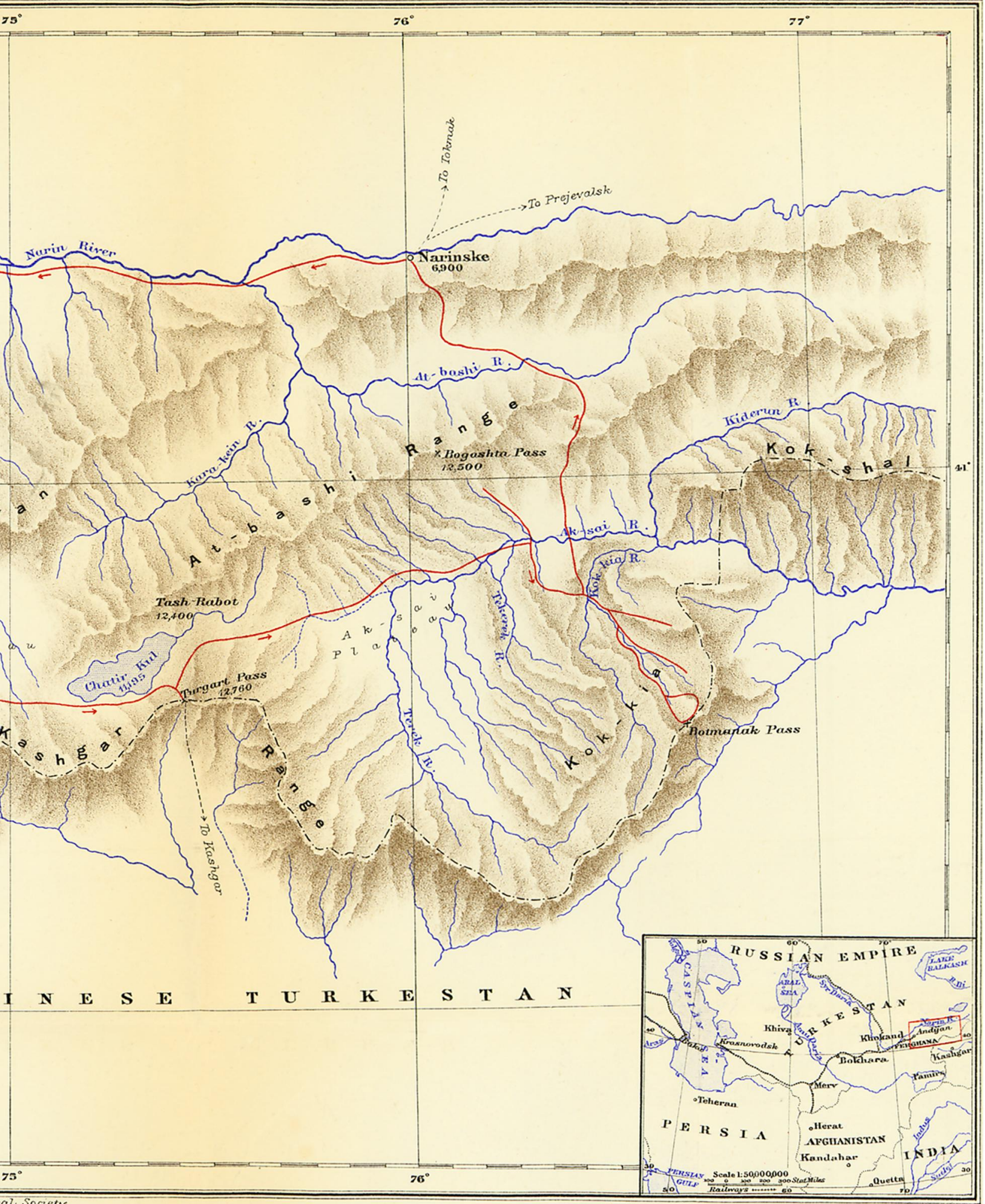

